\title{
Differential disease resistance response in the barley necrotic mutant nec1
}

\author{
Anete Keisa, Krista Kanberga-Silina, Ilva Nakurte, Laura Kunga and Nils Rostoks*
}

\begin{abstract}
Background: Although ion fluxes are considered to be an integral part of signal transduction during responses to pathogens, only a few ion channels are known to participate in the plant response to infection. CNGC4 is a disease resistance-related cyclic nucleotide-gated ion channel. Arabidopsis thaliana CNGC4 mutants hlm 1 and dnd2 display an impaired hypersensitive response (HR), retarded growth, a constitutively active salicylic acid (SA)-mediated pathogenesis-related response and elevated resistance against bacterial pathogens. Barley CNGC4 shares 67\% aa identity with AtCNGC4. The barley mutant nec1 comprising of a frame-shift mutation of CNGC4 displays a necrotic phenotype and constitutively over-expresses $P R-1$, yet it is not known what effect the necl mutation has on barley resistance against different types of pathogens.

Results: necl mutant accumulated high amount of SA and hydrogen peroxide compared to parental cv. Parkland. Experiments investigating necl disease resistance demonstrated positive effect of necl mutation on non-host resistance against Pseudomonas syringae pv. tomato (Pst) at high inoculum density, whereas at normal Pst inoculum concentration nec1 resistance did not differ from wt. In contrast to augmented $P$. syringae resistance, penetration resistance against biotrophic fungus Blumeria graminis f. sp. hordei (Bgh), the causal agent of powdery mildew, was not altered in nec1. The nec1 mutant significantly over-expressed race non-specific Bgh resistance-related genes Bl-1 and $M L O$. Induction of Bl-1 and MLO suggested putative involvement of nec1 in race non-specific Bgh resistance, therefore the effect of neclon mlo-5-mediated Bgh resistance was assessed. The nec1/m/o-5 double mutant was as resistant to Bgh as Nec1/mlo-5 plants, suggesting that necl did not impair mlo-5 race non-specific Bgh resistance.

Conclusions: Together, the results suggest that nec1 mutation alters activation of systemic acquired resistancerelated physiological markers and non-host resistance in barley, while not changing rapid localized response during compatible interaction with host pathogen. Increased resistance of necl against non-host pathogen Pst suggests that nec1 mutation may affect certain aspects of barley disease resistance, while it remains to be determined, if the effect on disease resistance is a direct response to changes in SA signaling.
\end{abstract}

\section{Background}

To date, numerous lesion mimic mutants (LMM) have been characterized in Arabidopsis thaliana, rice and maize $[1,2]$. Frequently, LMM display enhanced disease resistance, constitutive expression of pathogenesisrelated responses and an altered hypersensitive response (HR). Molecular mechanisms triggering the onset of cell death underlying the lesions mimic phenotype might have common features with HR-associated cell death observed during pathogen infection [3]. Although a direct link between HR and plant disease resistance is

\footnotetext{
* Correspondence: nils.rostoks@lu.lv

Faculty of Biology, University of Latvia, 4 Kronvalda Boulevard, Riga, LV-1586,
} Latvia

\section{() BioMed Central}

(c) 2011 Keisa et al; licensee BioMed Central Ltd. This is an Open Access article distributed under the terms of the Creative Commons Attribution License (http://creativecommons.org/licenses/by/2.0), which permits unrestricted use, distribution, and reproduction in any medium, provided the original work is properly cited. often questioned [3,4], it is evident that LMM can clarify numerous aspects of plant-pathogen interactions at the molecular level.

Although several barley mutants with necrotic leaf spots have been reported [5], only very few LMM phenotypes of barley have been traced down to a particular gene. The best known examples of barley LMM are mlo $[6,7]$, and the recently characterized necS1 (HvCAX1) [8], which apart from displaying a necrotic phenotype also shows enhanced disease resistance against fungal pathogens. The barley mutant nec1 comprising of a mutated cyclic nucleotide gated ion channel 4 (CNGC4) exhibits the necrotic phenotype and over-expresses the pathogenesis-related gene PR-1 [9]. A. thaliana CNGC4 
mutants $d n d 2$ and $h \operatorname{lm} 1$ which are orthologous to barley nec1 mutants display enhanced resistance to virulent bacterial pathogens $[10,11]$. HvCNGC4 shares $67 \%$ aa identity with AtCNGC4 [9], suggesting that a similarly to $d n d 2$ in A. thaliana nec1 mutation may affect barley disease resistance.

Bacterial diseases of barley have been described, although the mechanisms of resistance have not been studied in detail $[12,13]$. Apparently, there is no racespecific resistance to bacterial pathogens: thus, only PAMP-triggered immunity is operational, even though cultivar-dependent differences in infection rates have been reported for bacterial kernel blight caused by Pseudomonas syringae [14]. Significant over-production of salicylic acid (SA) upon $P$. syringae infection in barley suggests that barley resistance to non-host bacterial pathogens is achieved through a SA-mediated defense pathway [15].

Bacterial pathogens of Arabidopsis are commonly used as a model system for plant-pathogen interaction studies. However, fungal pathogens are the causal agents of economically more deleterious and widespread diseases in barley. Powdery mildew is caused by the biotrophic fungus Blumeria graminis f. sp. hordei $(B g h)$. This is among the best studied barley diseases, and extensive details are available on both the race specific or race non-specific powdery mildew resistance mechanisms [16]. Race non-specific resistance of barley to Bgh is a cell wall-based resistance forbidding fungal penetration into a host cell [17]. Penetration resistance is triggered by the ROR2 protein, presumably directing secretion vesicle trafficking to the fungal penetration site [18]. Race non-specific penetration resistance is fully attained only in the absence of the trans-membrane protein MLO which is a negative regulator of ROR2 [19]. Functional MLO protein employs $\mathrm{Ca}^{2+}$ and $\mathrm{CaM}$ signaling to ensure fungal penetration into host cells. Mutations negatively affecting MLO binding with CaM render barley more resistant against $B g h[19,20]$, while overexpression of another trans-membrane protein, BI-1, counteract mlo-triggered $\mathrm{Bgh}$ resistance in a $\mathrm{Ca}^{2+}$ and CaM signaling-dependent manner [21,22]. Although the interdependence of $\mathrm{Ca}^{2+} / \mathrm{CaM}$ signaling and race nonspecific $B g h$ resistance in barley is well established, so far no $\mathrm{Ca}^{2+}$ permeable ion-channel has been shown to participate in $B g h$ resistance or susceptibility.

Race specific resistance of barley against $B g h$ requires the presence of plant $R$-genes called $M l$ genes. In contrast to race non-specific $B g h$ resistance, race specific resistance usually permits fungal penetration into the host cell, but restricts further spread of the fungus by triggering plant cell death [16]. Both types of powdery mildew resistance have been shown to incorporate reactive oxygen species (ROS) signaling elements, such as increased accumulation of $\mathrm{H}_{2} \mathrm{O}_{2}$ and/or superoxide $[23,24] . \mathrm{H}_{2} \mathrm{O}_{2}$ acts as a principal signaling molecule initiating cell death during incompatible race-specific barley-Bgh interaction [24]. Early accumulation of $\mathrm{H}_{2} \mathrm{O}_{2}$ in mesophyll cells underlying attacked epidermal cells is proposed to be critical for the establishment of race specific resistance $[25,26]$. In race non-specific interactions, $\mathrm{H}_{2} \mathrm{O}_{2}$ plays a distinct role from that observed for $\mathrm{HR}$ induction. In mlo-triggered resistance, $\mathrm{H}_{2} \mathrm{O}_{2}$ most likely ensures host cell wall fortification, thus preventing fungal penetration $[23,27]$.

In this study, disease resistance of barley LMM nec1 mutants displaying necrotic leaf spots was analyzed. Although NEC1 has been shown to encode cyclic nucleotide gated ion channel 4 (CNGC4) and to overexpress the defense-related $P R-1$ gene [9], the effect of nec1 mutation on barley disease resistance has not yet been characterized. This study shows that nec1 mutation triggers the induction of $\mathrm{H}_{2} \mathrm{O}_{2}$ and SA, restricts Bgh microcolony formation and affects non-host resistance against Pseudomonas syringae applied at high inoculum density, whereas it has no effect on Bgh penetration efficiency or mlo-dependent race non-specific Bgh resistance.

\section{Results}

\section{nec1 mutant exhibits constitutive activation of $\mathrm{H}_{2} \mathrm{O}_{2}$ and} salicylic acid

The nec1 allele in cultivar Parkland was initially described as a natural mutation [28], which was confirmed by identification of a MITE insertion in an intron of the NEC1 gene that caused alternative splicing and a predicted non-functional protein [9]. The nec1 mutant line GSHO 1284 and a parental variety Parkland were genotyped with DArT markers [29]. Only $2.2 \%$ of 1131 DArT loci were polymorphic, suggesting that the mutant is essentially isogenic to Parkland (data not shown). All described experiments were performed with Parkland and its mutant nec1 accession GSHO 1284.

As it was found that nec1 significantly over-expressed pathogenesis related genes [9], it was investigated whether nec1 plants spontaneously display also other SAR-related signals such as altered accumulation of reactive oxygen species and over-accumulation of SA Spectrofluorimetric analysis of whole-leaf extracts of two week old nec1 plants with a fully developed lesion mimic phenotype and the parental line Parkland showed a three-fold higher overall level of $\mathrm{H}_{2} \mathrm{O}_{2}$ in the mutant (data not shown).

To ascertain whether the elevated overall amount of $\mathrm{H}_{2} \mathrm{O}_{2}$ in nec1 plants affected $\mathrm{H}_{2} \mathrm{O}_{2}$ accumulation during Bgh infection, overall $\mathrm{H}_{2} \mathrm{O}_{2}$ amount in nec1 and wt plants was assessed at $12 \mathrm{~h}$ and $36 \mathrm{~h}$ after inoculation with a virulent mixed population of Bgh. The analysis 
did not reveal considerable changes in the $\mathrm{H}_{2} \mathrm{O}_{2}$ content of wt plants during the first $36 \mathrm{~h}$ after inoculation, whereas nec1 mutants showed a slight, statistically nonsignificant increase in $\mathrm{H}_{2} \mathrm{O}_{2}$ levels at $36 \mathrm{~h}$ after inoculation (Figure 1).

$\mathrm{H}_{2} \mathrm{O}_{2}$ accumulation and $P R-1$ expression is known to be associated with SA-dependent signaling. Therefore, the SA content of nec1 and wt plants was also measured. HPLC assay confirmed that levels of free SA and conjugated SA were four- and fifteen-fold higher, respectively, in nec1 than in wt plants (Figure 2).

\section{Resistance of the nec1 mutant to Pseudomonas syringae}

Barley resistance to the non-host bacterial pathogen Pseudomonas syringae likely employs SA-mediated defense pathway [15]. Therefore, the constitutive activation of SA signaling in nec1 might contribute to its nonhost resistance. nec1 plants were inoculated with $P$. syringae pv. tomato (Pst) at two inoculum densities $-8 \times$ $10^{4}$ and $6 \times 10^{7} \mathrm{cfu} \mathrm{ml}^{-1}$ using vacuum infiltration technique. At day 3 after infiltration with $6 \times 10^{7} \mathrm{cfu} \mathrm{ml}^{-1}$ of Pst the amount of bacteria in nec1 was reduced, whereas Parkland had accumulated ca. 6-fold higher amount of Pst making the difference in bacterial growth between wt and nec1 statistically highly significant ( $\mathrm{p}=0.01$, Student's $t$-test) at this stage of infection (Figure $3 \mathrm{~A}$ ). Inoculation with Pst at lower inoculum density $\left(8 \times 10^{4}\right.$ $\mathrm{cfu} \mathrm{ml}^{-1}$ ) did not reveal any differences in resistance between nec1 and wt plants (Figure 3A).

Ion leakage measurements were also performed to characterize the effect of Pst infection on nec1 and

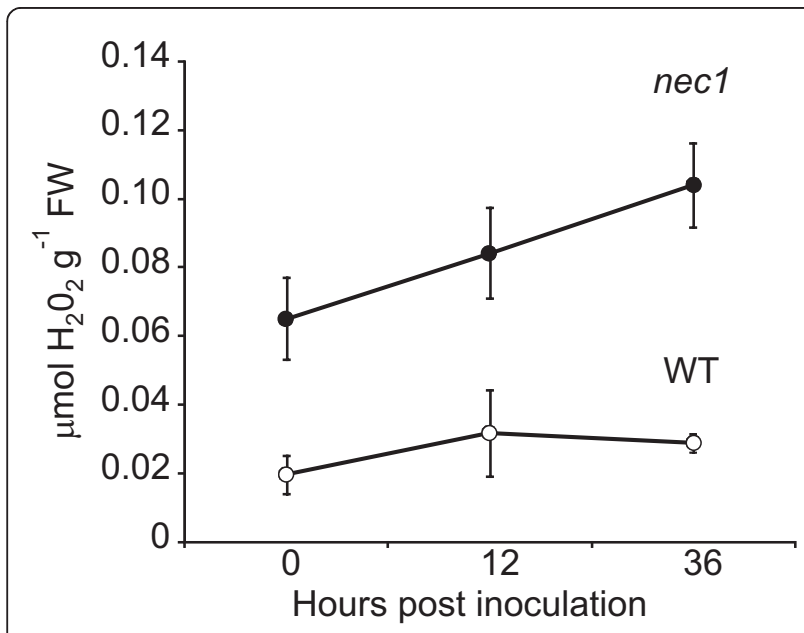

Figure 1 Time course of whole leaf $\mathrm{H}_{2} \mathrm{O}_{2}$ accumulation in nec1 and wt plants after $\mathbf{B g h}$ infection. necl mutation triggers $\mathrm{H}_{2} \mathrm{O}_{2}$ over-accumulation in barley in the absence of pathogen infection, but it does not alter time course of $\mathrm{H}_{2} \mathrm{O}_{2}$ production in response to $B g h$ infection. Error bars represent the standard deviation of means $(n=5$ per data point).

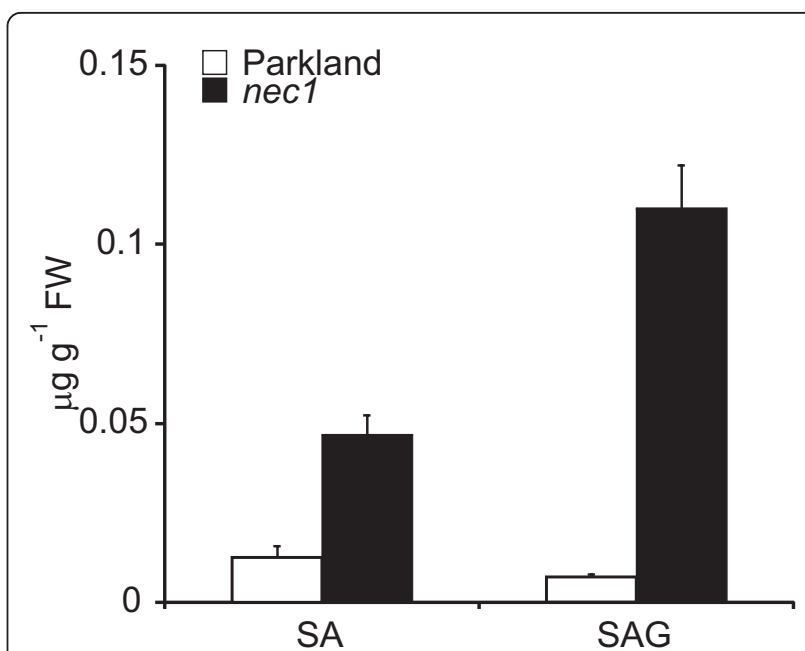

Figure 2 Level of free and conjugated SA in nec1 and wt plants. nec1 mutant contains significantly higher level of conjugated, as well as free SA compared to parental cv. Parkland. SA content was analyzed using reverse-phase high performance liquid chromatography in leaf tissue extracts of 14 day old plants. Average values from three biological replicates are presented, each consisting of three technical replicates. Error bars represent standard deviation.

Parkland. Vacuum infiltration with Pst at lower inoculum density $\left(8 \times 10^{4} \mathrm{cfu} \mathrm{ml}^{-1}\right)$ did not elicit cell death in either nec1 or Parkland (Figure 3B). In contrast to inoculation with lower Pst density, inoculation with Pst at $6 \times 10^{7} \mathrm{cfu} \mathrm{ml}^{-1}$ elicited differential response in nec1 and wt. Tissue samples from nec1 plants inoculated with Pst at $6 \times 10^{7} \mathrm{cfu} \mathrm{ml}^{-1}$ displayed more pronounced ion leakage suggesting an increased cell death in nec1 after infection (Figure 3B).

\section{Resistance of nec1 mutant to powdery mildew Blumeria graminis f.sp. hordei}

Since nec1 plants exhibited constitutively active defense responses, the role of nec1 in basal resistance against $B g h$ was assessed. Due to their basal resistance, even susceptible barley cultivars are able to restrict infection to some extent. In order to assess the effect of nec1 mutation on basal Bgh resistance, microcolony formation was examined. nec1 supported formation of significantly ( $\mathrm{p}<0.001, t$-test) smaller number of $B g h$ colonies compared to wt plants (Figure 4). To further test, if restricted formation of $\mathrm{Bgh}$ microcolonies on nec1 derived from the rapid and effective localized response precluding fungal penetration or from post-invasive defense impeding further fungal development, we examined nec1 Bgh penetration resistance. The effect of nec1 mutation on $B g h$ penetration resistance was characterized as the proportion of interaction sites that had formed Bgh haustoria to the total number of Bgh spores 


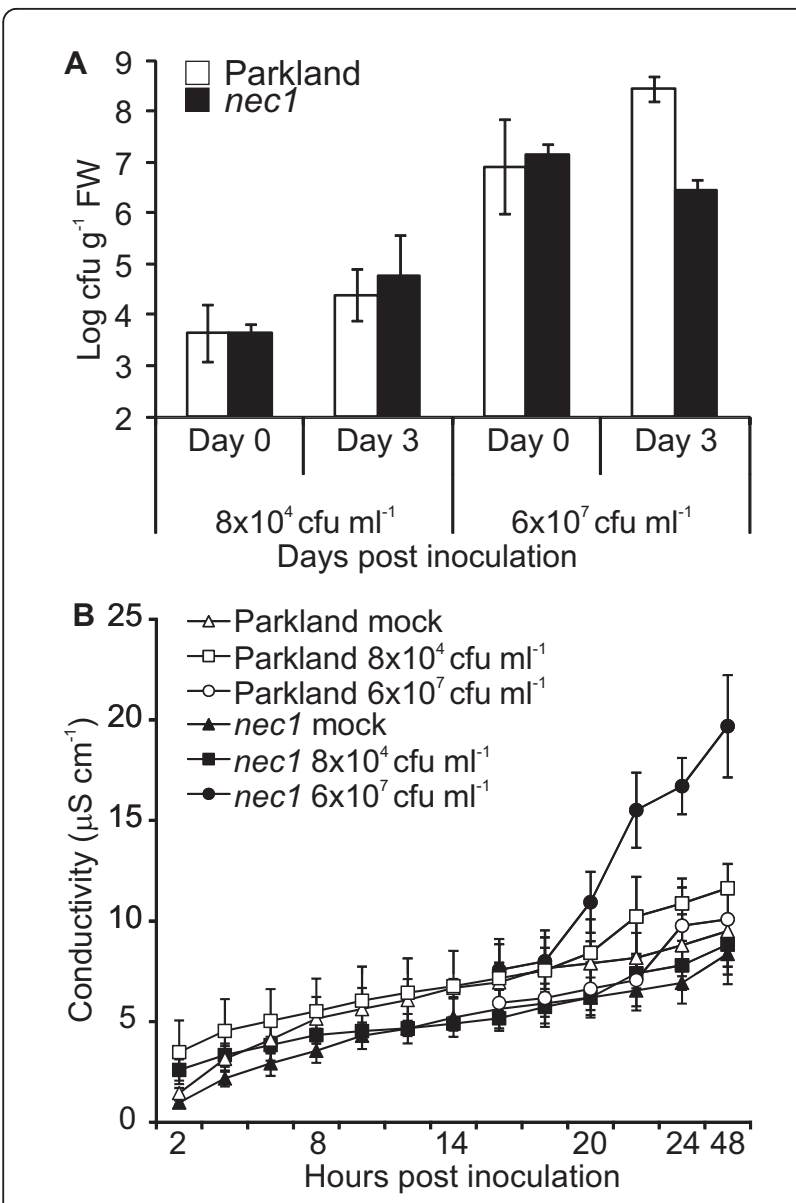

Figure 3 Response of nec1 to non-host pathogen Pseudomonas syringae pv. tomato applied at low and high inoculum densities. Panel A. Growth of Pseudomonas syringae pv. tomato in necl and parental cv. Parkland was monitored immediately and 3 days after vacuum infiltration with Pst applied at inoculum densities of $8 \times 10^{4}$ or $6 \times 10^{7} \mathrm{cfu} \mathrm{ml}^{-1}$. For mock inoculation plants were infiltrated with $10 \mathrm{mM} \mathrm{MgCl}$. Infection was expressed as number of colony forming units (cfu) per gram of fresh leaves (FW). Due to the high between-experiment variation, results of one representative experiment out of four independent experiments are shown. Error bars represent standard deviation. At high inoculum density $(6 \times$ $10^{7} \mathrm{cfu} \mathrm{ml}^{-1} 1$ ) bacterial cfu number in necl at the day 3 was significantly ( $p<0.01$, Student's $t$-test) lower than in wt. Panel B. Progression of cell death in necl and Parkland after infection with Pseudomonas syringae pv. tomato in the experiment shown in panel A. nec1 mutation showed increased electrolyte leakage in barley inoculated with non-host bacteria Pst at $6 \times 10^{7} \mathrm{cfu} \mathrm{ml}^{-1}$.

Measurements of electrolyte leakage were taken every two hours during 24 hour period and at 48 hours after inoculation. Error bars represent standard deviation.

that had germinated at 48 hpi. nec1 plants permitted almost identical entry and haustoria establishment rate of Bgh as the parental line (71\% and 74\% Bgh penetration efficiency respectively, $\mathrm{p}=0.64$, Student's $t$-test).

Basal Bgh resistance has been shown to be tightly linked to the molecular mechanisms of race-specific Bgh

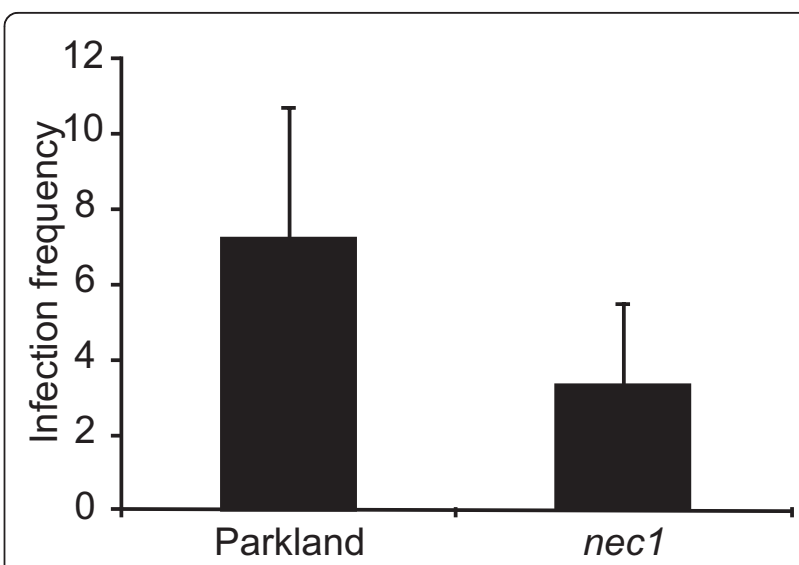

Figure 4 Bgh microcolony formation on nec 1 and wt plants Excised segments of barley leafs were inoculated with a virulent Bgh isolate. Microcolony formation was inspected microscopically 4 days post infection and infection rate was expressed as a number of microcolonies per $\mathrm{cm}^{-2}$ leaf area. Figure reflects data from two independent experiments. Error bars represent standard deviation. Infection frequency significantly differs between necl and Parkland $(p<0.001, t$-test $)$

resistance triggered by different $M l a$ alleles [30,31]. $H v R b o h A$ and $H v R a c B$ are known to participate in basal as well as race-specific Bgh resistance [32-34]. The expression of these genes was characterized using realtime quantitative PCR. Relative mRNA abundance of the analyzed genes was not affected by nec1 mutation (Figure 5) indirectly suggesting that nec1 may be independent from effector-triggered immunity that ensure rapid localized Bgh resistance.

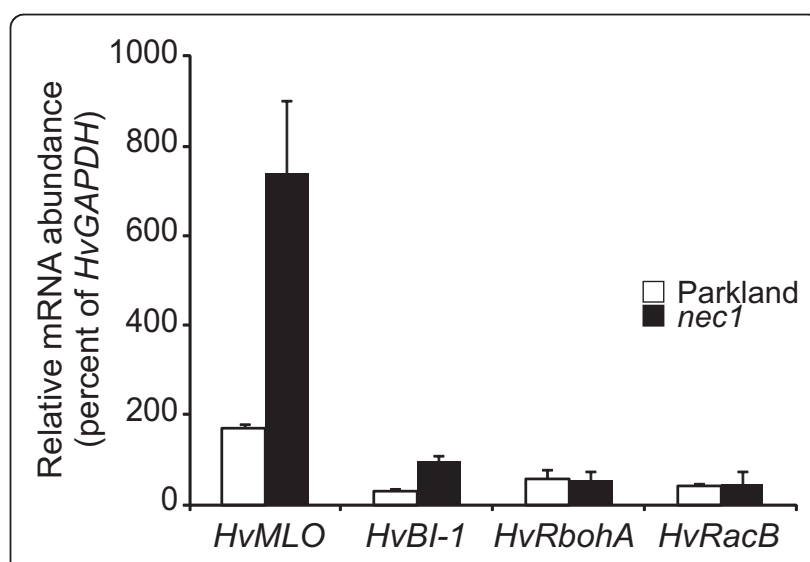

Figure 5 Effect of nec 1 mutation on expression of powdery mildew resistance related genes. Transcript abundance of powdery mildew resistance related genes in nec 1 mutants was determined by quantitative real time PCR. mRNA abundance of HVMLO and HVBl-1 is significantly increased in nec1. Error bars represent standard deviation. 
nec1 mutation alters expression of $B I-1$ and $M L O$, but does not affect $\mathrm{mlo}$-5-triggered race non-specific powdery mildew resistance

Different powdery mildew resistance types employ at least partially distinctive molecular pathways: thus, a particular gene can have a significant role in one Bgh resistance strategy, while having only a marginal or no effect on another $\mathrm{Bgh}$ resistance type [35]. To find out, if nec1 mutation affected mlo-triggered race non-specific $B g h$ resistance, the expression of $M L O$ and $B I-1$ genes was analyzed using real-time quantitative PCR. Loss of functional MLO protein renders barley almost fully resistant against $B g h$, whereas $B I-1$ over-expression in mlo mutants leads to restoration of susceptibility against $B g h$ [22] and, in fact, $B I-1$ is required for full susceptibility of barley to powdery mildew [36]. Furthermore, overexpression of $M L O$ in wild type plants leads to super susceptibility against Bgh [20]. Significant over-expression of both $M L O$ and $B I-1$ in nec1 plants was observed (Figure 5). To further test whether nec1 mutation had any effect on race non-specific powdery mildew resistance conferred by mlo-5 mutation, Bgh penetration resistance of nec1/mlo-5 double mutant was characterized. Similar to mlo-5 mutant, nec $1 /$ mlo-5 plants were almost fully resistant to $B g h$, allowing establishment of fungal haustoria only at less than $2 \%$ of interaction sites (Figure 6). In addition, the $\mathrm{H}_{2} \mathrm{O}_{2}$ content of whole-leaf extracts from nec1/mlo-5 double mutants was analyzed. While the nec1 mutant showed markedly increased accumulation of $\mathrm{H}_{2} \mathrm{O}_{2}$ compared to wt NEC1 plants, the experiment did not reveal a significant effect of $m l o-5$ mutation on $\mathrm{H}_{2} \mathrm{O}_{2}$ over-accumulation in nec1 (Figure 7).

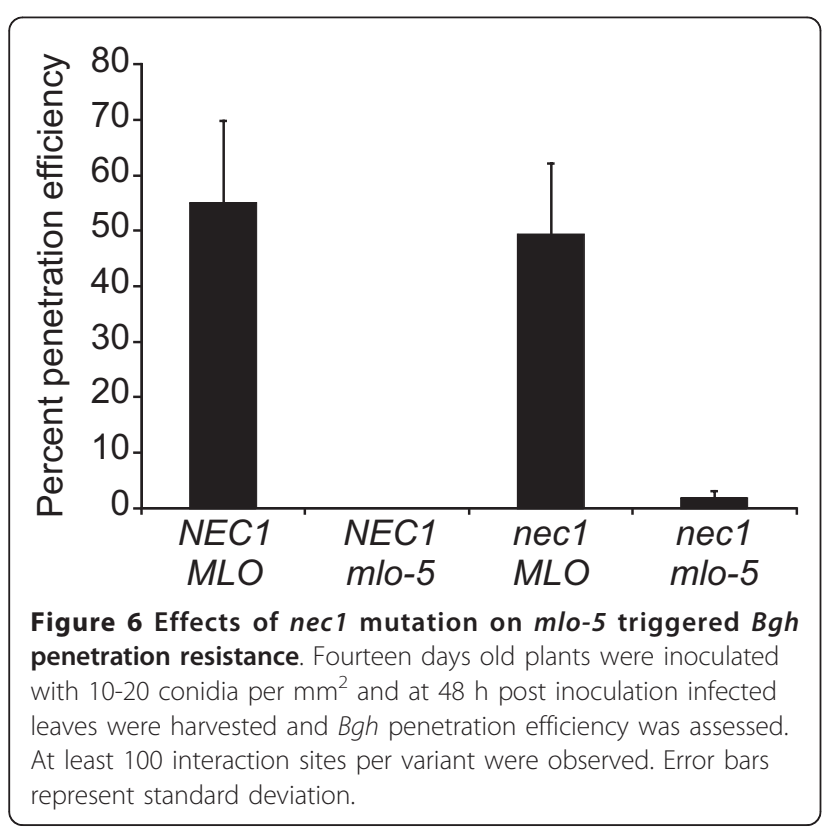

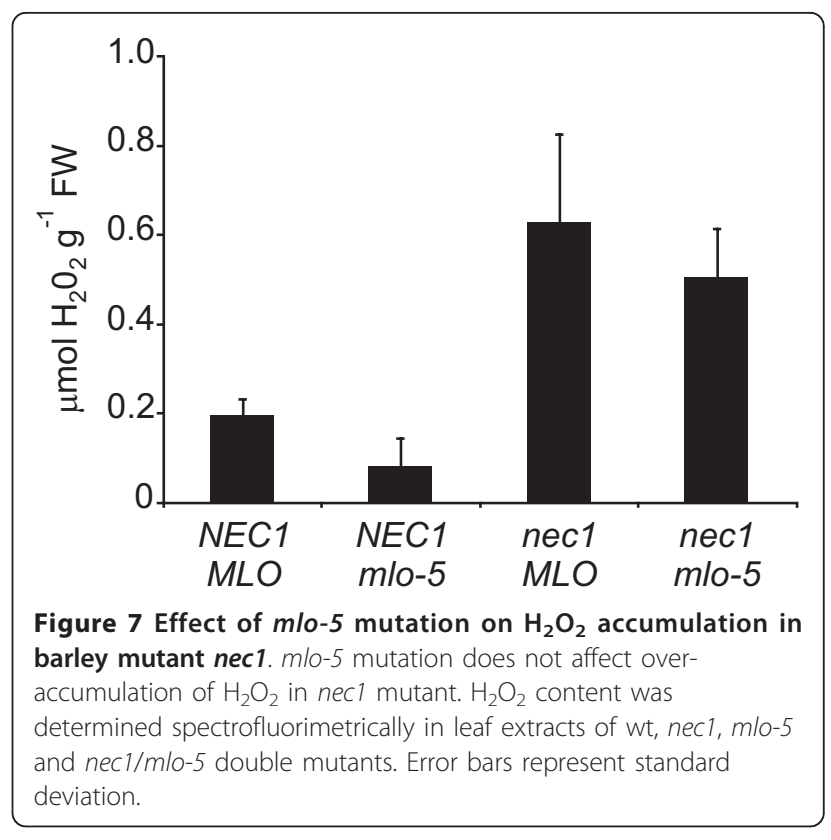

\section{Discussion}

Despite the fact that ion fluxes are known to play an important role in early signaling events during plantpathogen interaction [37-39], to date only several plant ion channels have been shown to participate in plant disease resistance or plant-pathogen interaction signal transduction. The cyclic nucleotide gated ion channel (CNGC) gene family is one of the best-represented among the disease resistance-related ion channels. CNGC mutants $d n d 1$ (AtCNGC2), dnd2 and $h l m 1$ (AtCNGC4) and cpr22 (AtCNGC11/12) exhibit a wide range of pathogen resistance $[10,11,40,41]$. Mutations affecting AtCNGC4 enhance resistance of Arabidopsis thaliana against certain pathotypes of Pseudomonas syringae and Botrytis cinerea [10,11,42]. Although the effect of CNGC mutations on resistance against bacterial and oomycete pathogens is well-studied in Arabidopsis, little is known about the role of these genes in non-host resistance and also about the functions of CNGCs in disease resistance of economically important monocot plant species such as barley. Here we show that similarly to $d n d 2$ in A. thaliana [10], nec1 in barley activates constitutive over-accumulation of SA. High level of SA contributes to enhanced disease resistance of $d n d 2$ to virulent Pseudomonas syringae pv. tomato $[10,42]$ and this resistance requires functional PAD4 [43], which is one of the central genes in SA-mediated effector-triggered immunity (ETI) [44] and SAR [45]. Although disease resistance pathways seem to be largely conserved among monocots and dicots [46-49], the position of SA in monocot immunity is ambiguous. Some monocots, such as rice, contain high endogenous SA levels [50] 
and $\mathrm{SA}$ is not required for $P R$-gene induction in rice upon infection [51]. Ineffectiveness of externally applied SA on induction of $P R$-genes has also been observed in barley [15] and wheat [52], however, inoculation with non-host bacteria Pseudomonas syringae triggers SA accumulation in barley [15]. Taking into account that such differences occur in the SA mediated resistance signaling among monocots and dicots, it is interesting to see whether mutation affecting SA mediated disease resistance in A. thaliana is also involved in barley disease resistance. The present study analyzed the effect of the nec1 ( HvCNGC4) mutation on barley resistance against Pseudomonas syringae pv. tomato and Blumeria graminis f. sp. hordei.

Mutation in the NEC1 gene affected barley non-host resistance against Pseudomonas syringae pv. tomato. Bacterial growth in nec1 plants was delayed at the initial phase of infection, if plants were inoculated with bacteria at high inoculum density. At the same time the increased electrolyte leakage suggested somewhat enhanced cell death, even though the conductivity values were much lower than reported for typical HR. Thus, electrolyte leakage data in necl were generally in agreement with the expected "defense, no death" phenotype characteristic of $h \operatorname{lm} 1 / d n d 2$ mutants, although differences between nec1 and hlm1/dnd2 mutants may exist in this respect. Non-host resistance is predicted to share common defense responses with host resistance - either basal (PAMP-triggered immunity, PTI) or ETI [53,54]. The choice of which layer of immunity is activated upon a particular interaction with nonhost pathogen seems to be case specific [55-57]. Therefore molecular mechanisms leading to changes in non-host resistance of nec1 to P. syringae pv. tomato might have also had an effect on interaction with host pathogens. This prompted the assessment of the role of nec1 mutation in resistance to powdery mildew caused by the fungal pathogen Blumeria graminis $\mathrm{f}$. $\mathrm{sp}$. hordei. nec1 restricted Bgh microcolony formation, while not affecting Bgh penetration or mlo-5 triggered resistance to $B g h$. Interestingly, despite the fact that nec 1 did not impede mlo-5 mediated race non specific resistance to $B g h, M L O$ and $B I-1$ mRNA abundance was significantly increased in barley nec1 plants (Figure 5). Significant over-expression of $M L O$ and $B I-1$ might result from general activation of cell death-related signaling pathways and systemic immunity responses rather than from activation of particular powdery mildew resistance. Together these observations suggest that nec1 mutation most likely affects PTI and nonhost resistance related responses and it is not associated with rapid localized defense responses required to prevent fungal penetration.
HR related cell death is suggested to serve in plant immunity as a factor triggering activation of SAR $[4,58]$. Spontaneous cell death might elicit constitutive activation of SAR related signaling pathway in nec1. Previously nec 1 has been shown to constitutively overexpress $P R-1 a$ and $\beta-1,3-$ glucanase [9] - molecular markers of SAR. This study confirmed the constitutive activation of SA-related signaling pathways in nec1 mutants, since significant over-accumulation of $\mathrm{H}_{2} \mathrm{O}_{2}$ and SA in nec1 plants was detected. In Arabidopsis thaliana, nonhost resistance against some types of pathogens involves SA signaling [59-61]. In barley, a substantial increase in SA levels has been observed after infection with Pseudomonas syringae pv. syringae, but not after inoculation with non-host fungus Blumeria (Erysiphe) graminis f. sp. tritici [15] or host pathogen Bgh [23] suggesting a differential role of SA in barley resistance against different pathogens. Constitutive activation of the SA-related defense pathway may contribute to differential resistance of nec1 mutant against non-host bacteria Pst and virulent host pathogen Bgh. However, the cause for SA over-accumulation needs further investigation, and it remains to be determined, if SA-independent pathways are activated in nec1 mutant similarly to Arabidopsis hlm1/dnd2 mutant.

\section{Conclusions}

nec1 mutation increased resistance against the non-host bacterial pathogen Pseudomonas syringae pv. tomato applied at high inoculum density and it also inhibited microcolony formation of host pathogen Blumeria graminis f.sp. hordei, but its penetration resistance to Bgh or race non-specific $B g h$ resistance pathways were not impaired. The differential disease resistance response of nec1 plants might result from the activation of specific resistance pathways differentiating between various types of pathogens. SA-dependent signaling pathways have previously been shown to participate in disease resistance against certain types of pathogens, while not affecting others. nec1 mutant displays constitutive activation of systemic acquired resistance-related signals such as over-accumulation of hydrogen peroxide and $\mathrm{SA}$, as well as over-expression of $P R-1$. It remains to be determined, if constitutive activation of SA related signaling is the main reason for the differential disease resistance of nec1 mutant.

\section{Methods}

\section{Plants}

Plants for all experiments were grown in an environmental growth chamber at $22^{\circ} \mathrm{C}$ under long-day $(16 \mathrm{~h}$ day, $8 \mathrm{~h}$ night), medium light (ca. $150 \mu \mathrm{mol} \mathrm{m}^{-2} \mathrm{~s}^{-1}$ ) conditions. The barley necrotic mutant nec1 (GSHO 
1284) containing a MITE insertion in the gene for Cyclic Nucleotide Gated Ion Channel 4 (CNGC4) [9] has previously been described as a natural mutant in cv. Parkland [28]. Both cv. Parkland and GSHO 1284 are completely susceptible to powdery mildew. mlo-5 and nec1 double mutant was obtained by crossing accession GSHO 1284 with NGB 9276 carrying the mlo-5 allele in the cv. Carlsberg II background [62]. Plants homozygous for nec 1 and mlo-5 alleles were confirmed by genotyping the respective mutations and $\mathrm{F}_{4}$ plants were used for all experiments. Barley accessions GSHO 1284 and Parkland were obtained from USDA ARS National Small Grains Germplasm Research Facility (Aberdeen, Idaho, USA), and NGB 9276 was obtained from Nordic Genetic Resources Center (Alnarp, Sweden).

\section{Infection with Pseudomonas syringae pv. tomato}

To study nec1 non-host resistance against Pseudomonas syringae pv. tomato, leaves of 14 day old nec1 plants were vacuum infiltrated with a bacterial suspension in $10 \mathrm{mM} \mathrm{MgCl} 2$. Bacterial suspension was applied at normal concentration $8 \times 10^{4}$ and high concentration $6 \times$ $10^{7} \mathrm{cfu} \mathrm{ml}^{-1}$, since low concentration inoculum typically applied for infection of host plants can have minor or no effect on non-host species [63]. For mock inoculation $10 \mathrm{mM} \mathrm{MgCl}{ }_{2}$ was used for infiltration. Immediately after infiltration plants were covered with plastic bags to maintain high humidity and kept in dark for $1 \mathrm{~h}$. After an hour plants were transferred to growth conditions described above. Bacterial growth was monitored at day 3 post inoculation by dilution plating of homogenized plant tissue. Leaves were briefly sterilized with $70 \%$ ethanol before homogenization. Pseudomonas syringae pv. tomato was obtained from the German microbial type collection (accession 50315).

\section{Cell death measurements}

Cell death was quantified by electrolyte leakage assay performed as described by Dellagi et al. (1998) with minor modifications [64]. In brief, plants were vacuum infiltrated with Pst as described above and incubated in dark at high humidity for an hour. Five mm leaf disks were collected and washed with distilled water for $1 \mathrm{~h}$ and then transferred to a tube with $6.5 \mathrm{ml}$ distilled water. Conductivity was measured with conductivity meter handylab LF11 (Schott Instruments). Each sample contained 4 leaf disks from 4 plants and at each data point 4 independent replicates were measured.

\section{Fungal material, inoculation and calculation of penetration efficiency}

Two week old plants of nec1 and cv. Parkland were inoculated with 10-20 conidia per $\mathrm{mm}^{2}$ from virulent mixed population of powdery mildew multiplied on $\mathrm{cv}$.
Parkland. For the characterization of penetration efficiency, infected barley leaves were harvested $48 \mathrm{~h}$ post inoculation and cleared for $24 \mathrm{~h}$ in $98 \%$ ethanol. Penetration efficiency was calculated as a ratio of interaction sites with haustoria formation and the total number of spores with developed appresoria. The overall penetration efficiency for the particular barley line was an average from three replicates containing at least 100 interaction sites each.

Bgh microcolony formation was examined on $5 \mathrm{~cm}$ long leaf middle segments, which were laid flat on $0.5 \%$ agar in water $\left(\mathrm{w} \mathrm{v}^{-1}\right)$ plates with adaxial surface facing up and were inoculated with mixed population of powdery mildew multiplied on cv. Parkland. Each plate contained leaves from both nec1 and cv. Parkland plants to compensate for uneven inoculation. Bgh microcolonies were microscopically scored 4 days post inoculation. Experiment was repeated twice with 14 independent samples per barley line in each experiment.

\section{$\mathrm{H}_{2} \mathrm{O}_{2}$ detection and quantification}

Hydrogen peroxide was quantified spectrofluorometrically [65]. Briefly, $1 \mathrm{~g}$ of freshly harvested leaves from two week old barley plants were frozen in liquid nitrogen and ground in $50 \mathrm{mM}$ Hepes- $\mathrm{KOH}$ buffer containing $1 \mathrm{mM}$ EDTA and $5 \mathrm{mM} \mathrm{MgCl} 2$ (pH 7.5). After centrifugation for 10 minutes at $13000 \mathrm{~g}$, the supernatant was transferred to a new centrifuge tube and an equal volume of chloroform: methanol (volume ratio 2:1) solution was added. After centrifugation for 3 minutes at $13000 \mathrm{~g}$, the upper aqueous phase was transferred to a new centrifuge tube and 50 $\mathrm{mM}$ Hepes- $\mathrm{KOH}$ buffer solution ( $\mathrm{pH} 7.5$ ) containing 0.5 $\mathrm{mM}$ homovanillic acid and $15 \mathrm{U}$ horseradish peroxidase VI was added to a final volume of $3 \mathrm{ml}$. Samples were incubated at room temperature for 30 minutes before fluorescence measurements were taken (excitation at 315 $\mathrm{nm}$, emission at $425 \mathrm{~nm}$ ). Fluorescence was measured with a FloroMax3 spectrofluorometer (Horiba Scientific, Japan). For quantification of the $\mathrm{H}_{2} \mathrm{O}_{2}$ a standard curve with a range of $100 \mu \mathrm{M}-1 \mathrm{nM}$ was applied. Sample correction for quenching was performed by adding a known sample amount to a $10 \mathrm{nM} \mathrm{H}_{2} \mathrm{O}_{2}$ solution.

\section{Quantification of free and conjugated salicylic acid}

The SA content in leaf tissue extracts was analyzed using reverse-phase high performance liquid chromatography (HPLC). Each sample contained leaf tissue from 3 two week old plants. Samples were prepared essentially as described [66]. Briefly, $0.45 \mathrm{~g}$ barley leaf tissue was homogenized in liquid nitrogen and sequentially extracted using 90\% and 100\% methanol. Extraction was repeated twice and two supernatant fractions were pooled and dried. The residue was resuspended in $1 \mathrm{ml}$ of $5 \%$ acetic acid. As an internal standard for SA 
recovery correction, samples were selectively spiked with $50 \mu \mathrm{g}$ per g FW 3-hydroxy benzoic acid (3-HBA) [66].

For the quantification of free SA, $1 \mathrm{ml}$ of ethylacetate: cyclopentane:isopropanol (50:50:1) was added. The sample was thoroughly mixed and the upper phase (approximately $1 \mathrm{ml}$ ) was transferred to a new $2 \mathrm{ml}$ tube. The aqueous phase was then re-extracted, as described previously, and both organic phases (approximately $2 \mathrm{ml}$ ) were pooled. The resulting solution was vacuum-dried and thoroughly resuspended in $0.9 \mathrm{ml}$ of mobile phase. This suspension was filtered through a $0.20 \mu \mathrm{m}$ filter.

The aqueous phase containing the SAG fraction was acidified with $\mathrm{HCl}$ to $\mathrm{pH} 1.0$ and boiled for $30 \mathrm{~min}$ to separate free SA from conjugated SA. The released SA was then extracted with the organic mixture and treated as above.

Chromatographic analysis was performed on a modular HPLC system, Agilent 1100 series, consisting of quaternary pump, autosampler, column thermostat and both UV and fluorescence detectors (Agilent Technologies, Germany). Separation was achieved on a Zorbax Eclipse XDBC18 (Agilent Technologies, Germany) column $4.6 \times 250$ $\mathrm{mm}, 5 \mu \mathrm{m}$. Column temperature was maintained at $40^{\circ} \mathrm{C}$. The mobile phase was prepared by mixing acetonitrile:20 $\mathrm{mM} \mathrm{NaH} \mathrm{PO}_{4}$ (pH 3.0 with acetic acid), in a volume ratio 25:75. The mobile phase flow rate was $1.0 \mathrm{ml} \mathrm{min}^{-1}$. Injection volume was $100 \mu \mathrm{l}$. The UV/VIS detector was set to $237 \mathrm{~nm}$ and $303 \mathrm{~nm}$ and the fluorescence detector to an excitation wavelength of $297 \mathrm{~nm}$ and an emission wavelength of $407 \mathrm{~nm}$. Results were evaluated by a ChemStation Plus (Agilent, Germany).

\section{RNA extraction}

For RNA extraction, $5 \mathrm{~cm}$ long segments of cotyledon leaf from two week old plants of necrotic mutant nec1 and parental cv. Parkland were frozen in liquid nitrogen immediately after harvesting. Total RNA was extracted from frozen leaf tissues using Trizol reagent. Each RNA sample was extracted from a pool of five plants, and three biological replicates of each barley line (15 plants in total) were used for expression analysis of $B I-1, M L O$, $H \nu R A C B$ and $H v R b o h A$ genes in nec1 and cv. Parkland plants. Integrity of the extracted RNA was monitored using non-denaturing agarose gel electrophoresis. Quantity of purified total RNA was monitored using spectrophotometer NanoDrop ND-1000 (NanoDrop products, USA). One to two $\mu \mathrm{g}$ of the extracted RNA was treated with DNaseI (Fermentas, Vilnius, Lithuania) following the manufacturer's instructions and afterwards purified using chloroform-ethanol extraction.

\section{Reverse transcription and quantitative real-time PCR}

cDNA was synthesized with oligo $(\mathrm{dT})_{18}$ primers in a total volume of $10 \mu \mathrm{l}$ containing $1 \mu \mathrm{g}$ of total RNA
Table 1 Quantitative real-time PCR primer sequences used in the study

\begin{tabular}{lll}
\hline Primer & Sequence & Reference \\
\hline HvBI_cw1 & CGATGATCTCCTGCGTGTCG & This study * \\
HvBI_ccw1 & TACCTCGGTGGCCTGCTCTC & This study * \\
HvGAPDH_cw1 & CGTTCATCACCACCGACTAC & {$[67]$} \\
HvGAPDH_ccw1 & CAGCCTTGTCCTTGTCAGTG & {$[67]$} \\
MLO_F1 & GTCGAGCCCAGCAACAAGTCTTC & This study * \\
MLO_R1 & ACCACCACCTTCATGATGCTCAG & This study * \\
HvrbohA_F1 & CCGATCAGATGTATGCTCCA & {$[33]$} \\
HvrbohA_R1 & CAGAAGGCATTGAAGCCAGT & {$[33]$} \\
HvRACB_L01 & GGTAGACAAAGAACAAGGGCGAAGT & This study * \\
HvRACB_R01 & CACAAGGCAGGAAGAAGAGAAATCA & This study * \\
\hline
\end{tabular}

* Primers were designed using Primer 3 software [68] using the following gene sequences as a template: HvBI (HarvEST21 Unigene 3323; AJ290421); MLO (HarvEST21 Unigene 6351; Z83834); HvRacB (HarvEST21 Unigene 5202; AJ344223)

using the RevertAid H Minus First Strand cDNA synthesis kit (Fermentas, Vilnius, Lithuania).

For quantitative real-time PCR, aliquots of cDNA were amplified on an ABI Prism 7300 instrument (Applied Biosystems, Foster City, CA, USA) using the Maxima SYBR Green PCR kit (Fermentas, Vilnius, Lithuania) in a total volume of $20 \mu \mathrm{l}$ containing $2 \mu \mathrm{l}$ of cDNA and $0.3 \mu \mathrm{M}$ primers (Table 1 ). The reaction was carried out as follows: initial denaturing step for 15 min at $95^{\circ} \mathrm{C}$ followed by 35 cycles of $15 \mathrm{~s}$ at $94^{\circ} \mathrm{C}, 30 \mathrm{~s}$ at $60^{\circ} \mathrm{C}$ and $45 \mathrm{~s}$ at $72^{\circ} \mathrm{C}$ (data acquisition step). Standard curves for the quantification of the transcript levels were calculated from serial dilutions of appropriate cDNA fragments amplified from cv. Parkland. Transcript levels of the studied genes were expressed as a percentage of $H v G A P D H$ transcript value in the same sample. Combined values of two technical replicates of the three biological replicates $(n=6)$ were used to calculate the average values and standard deviations. Analysis of variance (ANOVA) of transcript abundance between the mutant and the corresponding parent was done in Microsoft Excel (Redmond, WA, USA).

\section{Acknowledgements}

The study was funded by Latvian Council of Science grant Z-6142-090, European Social Fund project 2009/0224/1DP/1.1.1.2.0/09/APIANIAA/055 and University of Latvia grant ZP-59. AK and LK are recipients of the European Social Fund scholarships (projects 2009/0138/1DP/1.1.2.1.2/09/IPIANIAA/004 and 2009/0162/1DP/1.1.2.1.1./09/IPIANIAA/004, respectively). Authors are grateful to the anonymous reviewers for their suggestions that helped to improve the manuscript.

\section{Authors' contributions}

AK designed and performed the study and drafted the manuscript. KKS and LK performed the disease resistance tests and gene expression analyses. IN performed HPLC analysis and helped to draft the manuscript. NR designed and performed the study and wrote the final manuscript. All authors have read and approved the submitted manuscript. 
Received: 15 September 2010 Accepted: 15 April 2011

Published: 15 April 2011

\section{References}

1. Lorrain S, Vailleau F, Balague C, Roby D: Lesion mimic mutants: keys for deciphering cell death and defense pathways in plants? Trends Plant $\mathrm{SC}$ 2003, 8:263-271.

2. Moeder W, Yoshioka K: Lesion mimic mutants: A classical, yet still fundamental approach to study programmed cell death. Plant Signal Behav 2008, 3:764-767.

3. Mur LA, Kenton P, Lloyd AJ, Ougham H, Prats E: The hypersensitive response; the centenary is upon us but how much do we know? J Exp Bot 2008, 59:501-520.

4. Heath MC: Hypersensitive response-related death. Plant Mol Biol 2000, 44:321-334.

5. Lundqvist U, Franckowiak J, Konishi T: New and revised descriptions of barley genes. Barley Genetics Newsletter 1997, 26:22.

6. Buschges R, Hollricher K, Panstruga R, Simons G, Wolter M, Frijters A, Van Daelen R, Van Der Lee T, Diergarde P, Groenendijk J, et al: The barley Mlo gene: A novel control element of plant pathogen resistance. Cell 1997, 88:695-705.

7. Wolter M, Hollricher K, Salamini F, Schulze Lefert P: The mlo resistance alleles to powdery mildew infection in barley trigger a developmentally controlled defence mimic phenotype. Mol Gen Genet 1993, 239:122-128.

8. Zhang L, Lavery L, Gill U, Gill K, Steffenson B, Yan G, Chen X, Kleinhofs A: A cation/proton-exchanging protein is a candidate for the barley NecS1 gene controlling necrosis and enhanced defense response to stem rust. Theor Appl Genet 2008, 118:385-397.

9. Rostoks N, Schmierer D, Mudie S, Drader T, Brueggeman R, Caldwell DG, Waugh R, Kleinhofs A: Barley necrotic locus nec1 encodes the cyclic nucleotide-gated ion channel 4 homologous to the Arabidopsis HLM1. Mol Genet Genomics 2006, 275:159-168.

10. Jurkowski Gl, Smith RK Jr, Yu IC, Ham JH, Sharma SB, Klessig DF, Fengler KA, Bent AF: Arabidopsis DND2, a second cyclic nucleotide-gated ion channel gene for which mutation causes the "defense, no death" phenotype. Mol Plant Microbe Interact 2004, 17:511-520.

11. Balague C, Lin B, Alcon C, Flottes G, Malmstrom S, Kohler C, Neuhaus G, Pelletier G, Gaymard F, Roby D: HLM1, an essential signaling component in the hypersensitive response, is a member of the cyclic nucleotidegated channel ion channel family. Plant Cell 2003, 15:365-379.

12. Mathre DE: Compendium of barley diseases St. Paul, Minnesota: The American Phytopathological Society; 1997

13. Georgakopoulos DG, Sands DC: Epiphytic populations of Pseudomonas syringae on barley. Canadian Journal of Microbiology 2010, 38:111-114.

14. Martinez-Miller C, Braun SL, Siemsen SL, Sands DC: Etiology of basal kernel blight of barley caused by Pseudomonas syringae pv. syringae. Canadian Journal of Plant Pathology 1997, 19:337-346.

15. Vallelian-Bindschedler L, Metraux JP, Schweizer P: Salicylic acid accumulation in barley is pathogen specific but not required for defense-gene activation. Molecular Plant-Microbe Interactions 1998, 11:702-705.

16. Hueckelhoven R, Kogel $\mathrm{KH}$ : Reactive oxygen intermediates in plantmicrobe interactions: Who is who in powdery mildew resistance? Planta 2003, 216:891-902.

17. Schulze-Lefert P: Knocking on the heaven's wall: pathogenesis of and resistance to biotrophic fungi at the cell wall. Curr Opin Plant Biol 2004, 7:377-383

18. Underwood W, Somerville SC: Focal accumulation of defences at sites of fungal pathogen attack. J Exp Bot 2008, 59:3501-3508.

19. Bhat RA, Miklis M, Schmelzer E, Schulze-Lefert P, Panstruga R: Recruitment and interaction dynamics of plant penetration resistance components in a plasma membrane microdomain. Proc Natl Acad Sci USA 2005, 102:3135-3140

20. Kim MC, Panstruga R, Elliott C, Mueller J, Devoto A, Yoon HW, Park HC, Cho MJ, Schulze-Lefert P. Calmodulin interacts with MLO protein to regulate defence against mildew in barley. Nature 2002, 416:447-450.

21. Ihara-Ohori Y, Nagano M, Muto S, Uchimiya H, Kawai-Yamada M: Cell death suppressor Arabidopsis bax inhibitor-1 is associated with calmodulin binding and ion homeostasis. Plant Physiol 2007, 143:650-660.
22. Hueckelhoven R, Dechert C, Kogel KH: Overexpression of barley BAX inhibitor 1 induces breakdown of mlo-mediated penetration resistance to Blumeria graminis. Proc Natl Acad Sci USA 2003, 100:5555.

23. Hueckelhoven R, Fodor J, Preis C, Kogel KH: Hypersensitive cell death and papilla formation in barley attacked by the powdery mildew fungus are associated with hydrogen peroxide but not with salicylic acid accumulation. Plant Physiol 1999, 119:1251-1260.

24. Hueckelhoven R: Powdery mildew susceptibility and biotrophic infection strategies. FEMS Microbiol Lett 2005, 245:9-17.

25. Hueckelhoven R, Fodor J, Trujillo M, Kogel KH: Barley Mla and Rar mutants compromised in the hypersensitive cell death response against Blumeria graminis f.sp. hordei are modified in their ability to accumulate reactive oxygen intermediates at sites of fungal invasion. Planta 2000, 212:16-24

26. Vanacker $\mathrm{H}$, Carver $\mathrm{TL}$, Foyer $\mathrm{CH}$ : Early $\mathrm{H}_{2} \mathrm{O}_{2}$ accumulation in mesophyll cells leads to induction of glutathione during the hyper-sensitive response in the barley-powdery mildew interaction. Plant Physiol 2000, 123:1289-1300

27. Collins NC, Thordal-Christensen H, Lipka V, Bau S, Kombrink E, Qiu JL, Huckelhoven R, Stein M, Freialdenhoven A, Somerville SC, et al: SNAREprotein-mediated disease resistance at the plant cell wall. Nature 2003, 425:973-977.

28. Fedak $G$, Tsuchiya $T$, Helgason SB: Use of monotelotrisomics for linkage mapping in barley. Can J Gen Cytol 1972, 14:949-957.

29. Wenzl P, Carling J, Kudrna D, Jaccoud D, Huttner E, Kleinhofs A, Kilian A: Diversity Arrays Technology (DArT) for whole-genome profiling of barley. Proc Natl Acad Sci USA 2004, 101:9915-9920.

30. Caldo RA, Nettleton D, Peng J, Wise RP: Stage-specific suppression of basal defense discriminates barley plants containing fast- and delayedacting Mla powdery mildew resistance alleles. Mol Plant Microbe Interact 2006, 19:939-947.

31. Shen QH, Saijo Y, Mauch S, Biskup C, Bieri S, Keller B, Seki H, Ulker B, Somssich IE, Schulze-Lefert P: Nuclear activity of MLA immune receptors links isolate-specific and basal disease-resistance responses. Science 2007, 315:1098-1103.

32. Schultheiss H, Dechert C, Kogel KH, Hueckelhoven R: A small GTP-binding host protein is required for entry of powdery mildew fungus into epidermal cells of barley. Plant Physiol 2002, 128:1447-1454.

33. Trujillo M, Altschmied L, Schweizer P, Kogel KH, Huckelhoven R: Respiratory burst oxidase homologue $A$ of barley contributes to penetration by the powdery mildew fungus Blumeria graminis f. sp. hordei. J Exp Bot 2006, 57:3781-3791.

34. Wong HL, Pinontoan R, Hayashi K, Tabata R, Yaeno T, Hasegawa $K$, Kojima C, Yoshioka H, Iba K, Kawasaki T, et al: Regulation of rice NADPH oxidase by binding of Rac GTPase to its N-terminal extension. Plant Cell 2007. 19:4022-4034.

35. Peterhansel C, Freialdenhoven A, Kurth J, Kolsch R, Schulze-Lefert P: Interaction analyses of genes required for resistance responses to powdery mildew in barley reveal distinct pathways leading to leaf cell death. Plant Cell 1997, 9:1397-1409.

36. Eichmann R, Bischof M, Weis C, Shaw J, Lacomme C, Schweizer P Duchkov D, Hensel G, Kumlehn J, Huckelhoven R: BAX INHIBITOR-1 is required for full ausceptibility of barley to powdery mildew. Mol Plant Microbe Interact 2010, 23:1217-1227.

37. MCDowell JM, Dangl JL: Signal transduction in the plant immune response. Trends Biochem Sci 2000, 25:79-82.

38. Dangl JL, Jones JDG: Plant pathogens and integrated defence responses to infection. Nature 2001, 411:826-833.

39. Nurnberger T, Scheel D: Signal transmission in the plant immune response. Trends Plant Sci 2001, 6:372-379.

40. Clough SJ, Fengler KA, Yu IC, Lippok B, Smith RK Jr, Bent AF: The Arabidopsis $d n d 1$ "defense, no death" gene encodes a mutated cyclic nucleotide-gated ion channel. Proc Natl Acad Sci USA 2000, 97:9323-9328.

41. Yoshioka K, Moeder W, Kang HG, Kachroo P, Masmoudi K, Berkowitz G, Klessig DF: The chimeric Arabidopsis CYCLIC NUCLEOTIDE-GATED ION CHANNEL11/12 activates multiple pathogen resistance responses. Plant Cell 2006, 18:747-763.

42. Genger RK, Jurkowski Gl, McDowell JM, Lu H, Jung HW, Greenberg JT, Bent AF: Signaling pathways that regulate the enhanced disease resistance of Arabidopsis "defense, no death" mutants. Mol Plant Microbe Interact 2008, 21:1285-1296. 
43. Jirage D, Zhou N, Cooper B, Clarke JD, Dong X, Glazebrook J: Constitutive salicylic acid-dependent signaling in cpr1 and cpr6 mutants requires PAD4. The Plant Journal 2001, 26:395-407.

44. Wiermer M, Feys BJ, Parker JE: Plant immunity: the EDS1 regulatory node. Curr Opin Plant Biol 2005, 8:383-389.

45. Durrant WE, Dong X: Systemic acquired resistance. Annu Rev Phytopathol 2004, 42:185-209.

46. Chern MS, Fitzgerald HA, Yadav RC, Canlas PE, Dong X, Ronald PC: Evidence for a disease-resistance pathway in rice similar to the NPR1mediated signaling pathway in Arabidopsis. Plant Journal 2001, 27:101-113.

47. Cooper B, Clarke JD, Budworth P, Kreps J, Hutchison D, Park S, Guimil S, Dunn $M$, Luginbuhl $P$, Ellero $C$, et al: A network of rice genes associated with stress response and seed development. Proc Natl Acad Sci USA 2003, 100:4945-4950.

48. Qiu D, Xiao J, Ding X, Xiong M, Cai M, Cao Y, Li X, Xu C, Wang S: OsWRKY13 mediates rice disease resistance by regulating defenserelated genes in salicylate- and jasmonate-dependent signaling. $\mathrm{Mol}$ Plant Microbe Interact 2007, 20:492-499.

49. Humphry M, Bednarek P, Kemmerling B, Koh S, Stein M, Gobel U, Stuber K, Pislewska-Bednarek M, Loraine A, Schulze-Lefert $P$, et al: A regulon conserved in monocot and dicot plants defines a functional module in antifungal plant immunity. Proc Natl Acad Sci USA 2010.

50. Chen Z, lyer S, Caplan A, Klessig DF, Fan B: Differential accumulation of salicylic acid and salicylic acid-sensitive catalase in different rice tissues. Plant Physiol 1997, 114:193-201.

51. Yang Y, Qi M, Mei C: Endogenous salicylic acid protects rice plants from oxidative damage caused by aging as well as biotic and abiotic stress. The Plant Journal 2004, 40:909-919.

52. Molina A, Gorlach J, Volrath S, Ryals J: Wheat genes encoding two types of PR-1 proteins are pathogen inducible, but do not respond to activators of systemic acquired resistance. Mol Plant Microbe Interact 1999, 12:53-58.

53. Mysore KS, Ryu CM: Nonhost resistance: how much do we know? Trends Plant Sci 2004, 9:97-104.

54. Jones JD, Dangl JL: The plant immune system. Nature 2006, 444:323-329.

55. Lipka U, Fuchs R, Lipka V: Arabidopsis non-host resistance to powdery mildews. Curr Opin Plant Biol 2008, 11:404-411.

56. Niks RE, Marcel TC: Nonhost and basal resistance: how to explain specificity? New Phytol 2009, 182:817-828.

57. Schweizer P: Nonhost resistance of plants to powdery mildew New opportunities to unravel the mystery. Physiological and Molecular Plant Pathology 2007, 70:3-7.

58. Kombrink E, Schmelzer E: The hypersensitive response and its role in local and systemic disease resistance. European Journal of Plant Pathology 2001, 107:69-78.

59. Yun BW, Atkinson HA, Gaborit C, Greenland A, Read ND, Pallas JA, Loake GJ: Loss of actin cytoskeletal function and EDS1 activity, in combination, severely compromises non-host resistance in Arabidopsis against wheat powdery mildew. The Plant Journal 2003, 34:768-777.

60. van Wees SC, Glazebrook J: Loss of non-host resistance of Arabidopsis NahG to Pseudomonas syringae pv. phaseolicola is due to degradation products of salicylic acid. The Plant Journal 2003, 33:733-742.

61. Zimmerli L, Stein M, Lipka V, Schulze-Lefert P, Somerville S: Host and nonhost pathogens elicit different jasmonate/ethylene responses in Arabidopsis. The Plant Journal 2004, 40:633-646.

62. Jorgensen $\mathrm{H}$ : Discovery, characterization and exploitation of $M / 0$ powdery mildew resistance in barley. Euphytica 1992, 63:141-152.

63. Lopez-Solanilla E, Bronstein PA, Schneider AR, Collmer A: HopPtoN is a Pseudomonas syringae Hrp (type III secretion system) cysteine protease effector that suppresses pathogen-induced necrosis associated with both compatible and incompatible plant interactions. Mol Microbiol 2004, 54:353-365.

64. Dellagi A, Brisset MN, Paulin JP, Expert D: Dual role of desferrioxamine in Erwinia amylovora pathogenicity. Mol Plant Microbe Interact 1998, 11:734-742.

65. Jimenez A, Creissen G, Kular B, Firmin J, Robinson S, Verhoeyen M, Mullineaux $P$ : Changes in oxidative processes and components of the antioxidant system during tomato fruit ripening. Planta 2002, 214:751-758.
66. Aboul-Soud MAM, Cook K, Loake GJ: Measurement of salicylic acid by a High-Performance Liquid Chromatography procedure based on ionexchange. Chromatographia 2004, 59:129-133.

67. Horvath H, Rostoks N, Brueggeman R, Steffenson B, von Wettstein D, Kleinhofs $A$ : Genetically engineered stem rust resistance in barley using the Rpg1 gene. Proc Natl Acad Sci USA 2003, 100:364-369.

68. Untergasser A, Nijveen $H$, Rao X, Bisseling T, Geurts R, Leunissen JA: Primer3Plus, an enhanced web interface to Primer3. Nucleic Acids Res 2007, 35:W71-W74.

doi:10.1186/1471-2229-11-66

Cite this article as: Keisa et al:: Differential disease resistance response in the barley necrotic mutant nec1. BMC Plant Biology 2011 11:66.

\section{Submit your next manuscript to BioMed Central and take full advantage of:}

- Convenient online submission

- Thorough peer review

- No space constraints or color figure charges

- Immediate publication on acceptance

- Inclusion in PubMed, CAS, Scopus and Google Scholar

- Research which is freely available for redistribution 